\title{
Active Aging and Happiness: European Senior Citizen Volunteers
}

\author{
Isabel Saz-Gil ${ }^{1}$ - Ana Isabel Gil-Lacruz ${ }^{2}$ - Marta Gil-Lacruz ${ }^{3}$ \\ Business Management Department, University of Zaragoza, Faculty of Social \\ and Human Sciences, Teruel, Spain \\ Business Management Department, University of Zaragoza, School of Engi- \\ neering and Architecture, Zaragoza, Spain \\ Department of Sociology and Psychology, University of Zaragoza, Nursing \\ School, Zaragoza, Spain
}

\begin{abstract}
Active Aging and Happiness: European Senior Citizen Volunteers. This paper studies the relationship between perceived happiness and volunteering among European senior citizens, paying special attention to differences based on gender and generational cohorts. The empirical analysis utilised micro data from the World Values Surveys (WVS: 1994/98, 2005/09 and 2010/14). The main conclusions are: i) Employment, education and income are key factors for understanding senior citizen volunteering and wellbeing; ii) senior citizen volunteering can be a positive factor that reinforces happiness if senior citizens chose activities that promote wellbeing; iii) it is important to encourage economic development that helps to improve the life conditions of all citizens.

Sociológia 2019, Vol. 51 (No. 3: 290-312)

https://doi.org/10.31577/sociologia.2019.51.3.14
\end{abstract}

Key words: Ageing; activity; Europe; wellbeing; social networks; volunteering

\section{Introduction}

Happiness, health and well-being are closely linked (Fitzpatrick et al. 2005). It is normally considered that good health and happinees are the most important determinants of wellbeing (Graham 2006), but also bad health and unhappiness have negative and lasting effects on well-being (Diener - Chan 2011), In 2008, the Sarkozy Commission suggested that a complementary indicator of national development should be based on health and happiness (Pierewan Tampubolon 2015). But this idea is not new. Bhutan has been the first country in the world to make the pursuit of happiness a state policy since the earlier 1970s. The philosophy of gross national happiness has several dimensions: it is integral (it recognizes the spiritual, material, physical or social needs of people), collective, sustainable from the ecological point of view and equitable

\footnotetext{
1 Address: Ph.D. Ma Isabel Saz-Gil, Business Management Department, University of Zaragoza, Faculty of Social and Human Sciences, Ciudad Escolar s/n, 44003 Teruel, Spain. Tfno: (+34) 978 645376, ext tel 86-1376. Fax: 978 618103. Email: sazgil@unizar.es

2 Address: Ph.D. Ana Isabel Gil-Lacruz, Business Management Department, University of Zaragoza, School of Engineering and Architecture, María de Luna, 3, Edificio Betancourt, Campus Río Ebro, 50018 Zaragoza, Spain. Tfno: (+34) 976 761000, ext tel 84-5206. E-mail: anagil@unizar.es

3 Address: Ph.D. Marta Gil-Lacruz, Department of Sociology and Psychology, University of Zaragoza, Nursing School, C/ Domingo Miral s/n, 50009 Zaragoza, Spain. Tfno: (+34) 976 764443. Fax: 976 761063. E-mail: mglacruz@ unizar.es
} 
(Sithey et al. 2015). Appropriate measures and specific interventions can promote not only citizens' health but also happiness (Norrish - Vella-Brodrick 2008).

The scientific literature provides strong empirical evidence on the benefits of volunteering on wellbeing (Dolan et al. 2008; Meier - Stutzer 2008; Thoits Hewitt 2001). Public decision makers also understand the importance of these interactions. Government agencies such as the Corporation for National and Community Service (2007) have encouraged people to volunteer due to the positive psychological impact that is generated by: expressions of gratitude; social approval; social recognition (Handy - Mook 2011), a sense of utility, feelings of productivity; and, social coherence (Ryff - Singer 2008). People also benefit from playing meaningful social roles (Baker et al. 2010) and the 'warm-glow' effect that results from helping others (Son - Wilson 2012).

Senior citizen volunteering might be even more beneficial for the older individual than started to volunteer at a young age (Van Willigen 2000). The explanation for these comparative advantages has much to do with the fact that senior citizen volunteering offers strategies for maintaining active and healthy lifestyles (Flecha 2015). Senior citizen volunteering improves the sense of social utility at a time of life which involves significant changes such as retirement and widowhood (Baker et al. 2005). Senior citizen volunteering can: protect against loneliness (Pinquart - Sörensen 2001), improve self-esteem (Chong et al. 2013), broaden and enrich the social network (Prouteau - Wolff 2008), develop social capital (Theurerand - Wister 2010; Echeverri et al. 2014), facilitate social integration (Berkman et al. 2000), and, bring a sense of transcendence and commitment to a social cause (Etzioni 2011).

Volunteering can strengthen social capital as it facilitates the construction of social networks, fosters cooperation among different institutional levels and generates trust and confidence (Matten et al. 2006). Helliwell (2001) points out that social capital influences a wide range of non-economic factors that increase the wellbeing of the population.

The main goal of this paper is to study how seniors' happiness gains from volunteering. Our main contributions are mainly two. First, we provide further empirical evidence about volunteering on wellbeing, taken into account four different kind of activities (Social Awareness, Politics \& Profession, Leisure \& Education and Religion) and one wellbeing indicator (Happiness). Second, we carry out an international comparison considering differences based on generational cohorts (Silent Generation and Baby Boomers) and gender.

We focus on European countries because they are facing the challenges of a rapidly aging population: in Europe there are currently four people in working age for every retired person and by 2050 this figure will be two people employed for every pensioner (Carone - Costello 2006). In addition, European 
governments are pursuing policies of austerity which involve public spending cuts aimed at reducing national debt. European welfare systems have to support a growing section of the population that is not making a direct economic contribution. There is a homogenisation process taking place with regards to the national statutory minimum retirement age and it is therefore relevant to examine geographical characteristics and the coexistence of different welfare systems in their efforts to implement effective social policies.

\section{Background}

The fulfilment of basic needs is a requirement for individual wellbeing. (Hervás 2009) Both high income and high levels of training and opportunities for learning facilitates happiness (Kye - Park 2014; Pinasart - Sörenssen 2001; Subas - Hayran 2005). In addition, factors as age, sex, civil status and employment status determine individual wellbeing (Stutzer - Frey 2006; Wilson 2000).

Predictors of wellbeing, happiness and health are similar (Oshio - Kobayashi 2010; Pierewan - Tampubolon 2015). In fact, happiness is associated with less stress, maintaining a healthy diet, exercise and even living in a healthy community (Kye - Park 2014).

Wellbeing should be defined through a number of approaches with particular emphasis on eudemonic and hedonic measures. From a hedonistic point of view, happiness concerns the maximisation of pleasure and the minimisation of pain. In contrast, as Ryan - Deci (2001) have argued, eudemonic happiness results from the actualisation of individual potential and fulfilment of the 'true' self. The same authors explored the advantages of volunteering in terms of purpose, meaning, fulfilment, social coherence, social contribution, social acceptance and social integration. Other authors, for example, McMahan - Renken (2011) have highlighted the importance of a sense of meaning of life with regards to self-reported wellbeing. Happiness is maximised when life activities are coincident with deeply held values, as this results in feelings of authenticity and aliveness (Waterman 1993).

Using a hedonic approach, Diener et al. (1999) identified three components of happiness: life satisfaction, the presence of positive feelings and the absence of negative feelings. In 2006, Diener studied happiness as a personal and integrated assessment of all domains that configure a person's life at a given point in time, or as an integrated judgment regarding the life trajectory. Volunteering provides opportunities to learn, to acquire new knowledge and skills, to become empowered and to feel part of a community and its history; these are all factors that provide a source of hedonic happiness (Ryan - Deci 2001; Thoits - Hewitt 2001). 
In fact, senior citizen volunteering is usually considered as a protective factor and health promoter. The positive health effects of volunteering include objective behaviours and conditions such as functional mobility, physical activity, the use of non-pharmacological pain-relieving methods (Tse et al. 2014) and prevention of early mortality (Konrath et al. 2012). These effects are also evident from a subjective perspective of wellbeing, volunteering can lead to: an improved emotional condition (Ho 2015; Morrow-Howell et al. 2010), reduced stress (Greenfield - Marks 2004), a moderation of the impact of functional limitations on depression (Greenfield - Marks 2007), and the mitigation of the intensity of pain (Tse et al. 2014).

Volunteering generates happiness by facilitating social bonds and providing individuals with feelings of satisfaction and self-respect (Seligman 2002; Thoits - Hewitt 2001). Social participation through volunteering allows older people to contribute to the common good, to bring about social improvements and to ensure continuity between generations (Villar et al. 2013).

There are statistically significant national differences regarding the impact of volunteering on the forming of human, social and cultural capital (Partboteeah et al. 2004). Economic living standard functions as moderator of the relationship between volunteering and happiness (Dulin et al. 2012). However, the causal relationship between these variables is complex. For example, in the relationship between volunteering and church attendance, Mollidor et al. (2015) suggest that part of the reason why church attendees with stronger religious beliefs present a higher degree of wellbeing is because they are more likely to volunteer.

In the European context, Norway is the country with the highest rate (67\%), Switzerland and Austria have a volunteering rate of $50 \%$, whilst the figure for Bulgaria, Poland, Russia, Estonia and Hungary is less than $20 \%$ (Huppert et al. 2009; Voicu - Voicu 2009). The low levels of volunteering in Eastern Europe may be due to the collapse of the Soviet Union (Kuti 2004). The Communist Party favoured participation in non-governmental organisations such as the Red Cross and levels of involvement rapidly declined after its collapse (Anheier Salamon 1999). Adding this constrictive factor, lower rate of volunteer in excommunist countries could be also explained by cultural and historical factors linked to a non-participative and pre-communist tradition (Voicu - Voicu 2009).

Therefore, national differences on volunteering rates are explained by sociodemographic, psychosocial, socioeconomic and cultural characteristics (Anheier-Salamon 1999; Piagnol - Huppert 2010) and macro variables (Kuti 2004).

World economic crisis returned the levels of employment and family income of 2005 to the levels of the 1990s, and this had an impact on rates of volunteering (Easterlin 2008). Macro variables, such as welfare system or 
GDP, influence both happiness and volunteering (Pierewan - Tampubolon 2015; Wallace - Pichler 2009). Welfare-state regimes differ in the redistribution of goods (for example, incomes and resources) and this affects the ways in which individuals can satisfy their needs (Sammuel - Hadjar 2016). Inequality is negatively related to both health and happiness (Oshio - Kobayashi 2010). The influence of this relationship depends on the cultural context. For example, the negative evaluation of inequality and happiness is more marked in Europe than in America. In Europe, people who are more sensitive to inequality feel worse (Pierewan - Tampubolon 2015). These cultural differences may reveal differences of values and beliefs about volunteering (Musick et al. 2000).

Within each country, this influence can be mediated by age cohorts, since values also matter. In a longitudinal study conducted in Hong Kong, Cheung and Cheng (2016) reported that age, income level and volunteering had more weight in explaining the wellbeing of the population in 2014 than in 2005.

Social participation among the Baby Boom Generation supposes a break with previous ideas concerning the older members of society (Olzabal 2009). A conceptual shift has been identified through an approach based on the protection of older people to one that affects the value of their participation (Raymond et al. 2013). Nevertheless, Komp and Johansson (2016) argue that Baby Boomers are less active than previous cohorts, although these findings require further research. Researchers, as Sekerak (2017), suggest that, present and future civic engagement in public life appear to be noteworthy in a EU context of increasing income inequality, characterised by growing intolerance or dissatisfaction with democracy. This is especially true for youth generations. However Twenge et al. (2016) believe that variations of happiness and civic engagement among North Americans are more due to cyclical variations than to generational variations.

\section{Data and empirical framework}

\section{Data}

The World Values Survey (WVS) provides a wealth of information for the study of the socioeconomic determinants and indicators of wellbeing. This study utilises the data from the last three surveys that are available: (1994 1998, $2005-2009$ and $2010-2014$ ), in order to ensure that the questions included in the questionnaires are comparable over time. The analysis is based on older adults, aged 51 to 70, from Germany, Poland, Romania, Russia, Slovenia, Spain, Sweden, Turkey and Ukraine.

Gender and generational differences were considered by means of 4 subsamples stratified by gender (Men and Women) and generational cohort (the 'Silent' Generation and the 'Baby Boom' Generation). The Silent Generation 
comprises people born between 1925 and 1949; Baby Boomers are those citizens that were born between 1950 and 1965 (Lancaster - Stillman 2004).

Although happiness is a multifaceted concept, it is usually studied by means of a single, direct question (Piagnol - Huppert 2010) which reveals significant relationships with sociodemographic characteristics (Frey - Stutzer 2002; Layard 2005; Piagnol - Huppert 2010; Pierewan - Tampubolon 2015). International instruments such as the World Values Survey (WVS) or the European Social Survey (ESS) use single item (Meier - Stutzer 2008). Therefore, the indicator of wellbeing is self-reported happiness on a scale of 1 to $5(1=$ excellent; $5=$ very poor). A dummy variable (Happy) was defined $(1=$ excellent or very good; $0=$ otherwise).

Figure 1: Percentages of European senior citizens who feel happy and who volunteer: by gender and birth cohorts

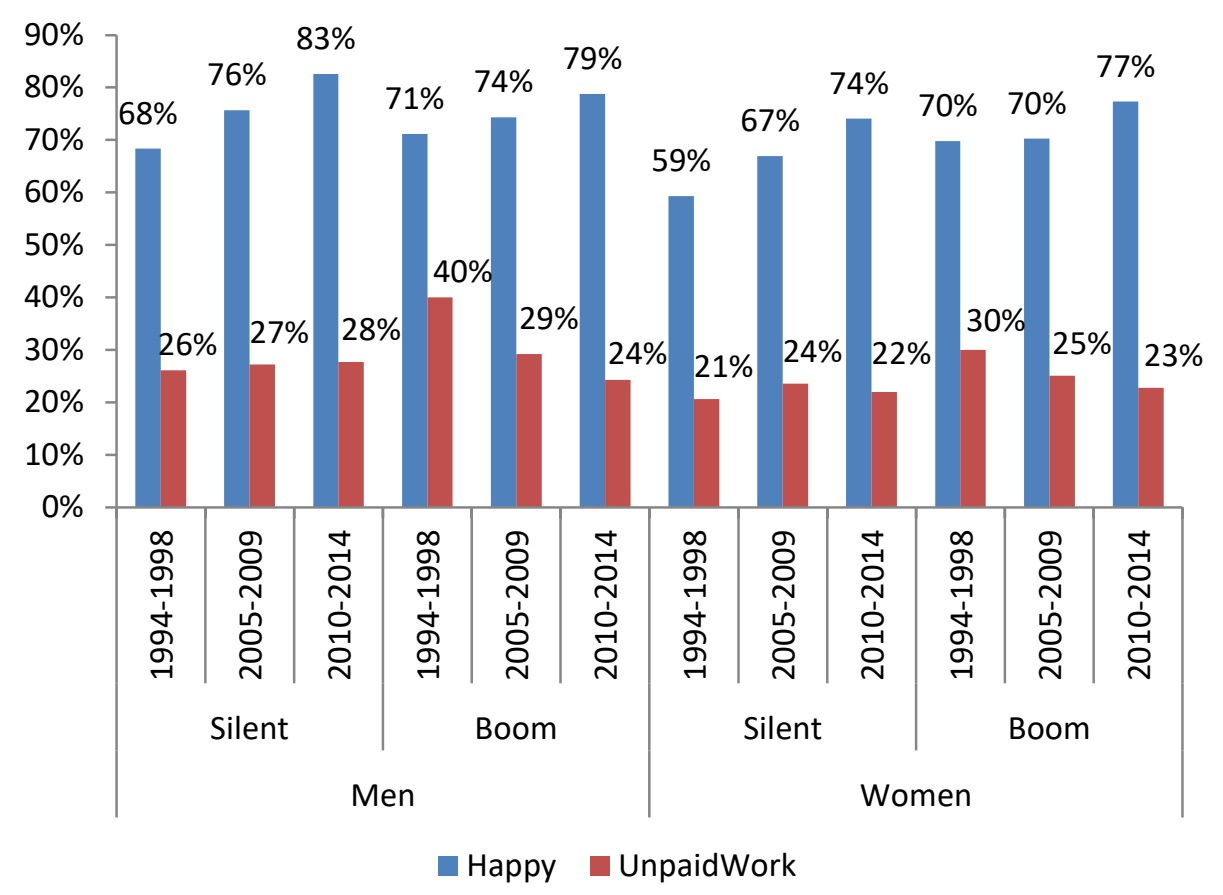

Data: World Value Survey (figure designed by the authors).

Volunteering is defined as the person being an active member of a not-forprofit organisation. The WVS considers voluntary participation in 11 different activities. For the sake of simplicity, in this study, voluntary work was categorised in 4 groups (Sardinha 2010): 1) Social awareness: activities related to human rights, animal rights or the environment; 2) Profession and Politics: 
activities related to trade unions, political parties and professional associations; 3) Education and Leisure: activities related to education, culture, youth work, sports or leisure; 4) Religion: activities related to the church or religious organisations. Volunteering on issues of social awareness and religion are considered as extrinsic motivations; volunteering in the areas of professional, sports and leisure are considered as intrinsic motivations. There is one general dummy variable $U W$ (AllCategories), and four category-based dummy variables: $U W($ SocialAwareness $), \quad U W($ Politics\&Profession), UW(Leisure\&Education) and $U W($ Religion).

Figure 1 shows the self-assessed levels of happiness among older adults that volunteer. Men from the Silent Generation appear to be the happiest $(83 \%$, 2010 - 2014). The lowest rate of happiness was found for women from the Silent Generation (59\% for the survey year 1994 - 1998). Men report higher levels of happiness than women. Differences by generational cohorts do not follow a significant pattern, although differences among people from the Silent Generation and the Baby Boom Generation are closer in the more recent surveys. Women from the Silent Generation are the less likely to volunteer ( $21 \%$ for the survey year 1994 - 1998), while men from the Baby Boom Generation are the most likely (40\% for the survey year $1994-1998)$. Volunteering rates remain constant for people from the Silent Generation and they decrease for Baby Boomers. The most recent volunteering rates for Baby Boomers are similar to those of the Silent Generation.

Older adults living in Sweden report both the highest rates of happiness and volunteering participation. (Figure 2) In contrast, older people from Russia report the lowest rates of happiness (around 70\%) and one of the lowest volunteering rates (under $10 \%$ ). However, the relationship between happiness and volunteering is not a simple one: for example, people from Poland show high rates of happiness (over $90 \%$ ) but low volunteering rates (around $20 \%$ ).

Table 1 gives the population distribution by dependent and explanatory variables. Men and Baby Boomers are happier than women and people from the Silent Generation. Gender differences reduce for Baby boomers over time. Women are less likely to volunteer than men, especially for political and professional activities. There is a higher percentage of married men than married women among people from the Silent Generation, this might be explained by the higher percentage of widows among women than among men for the same generation: female life expectancy is higher. Divorce rates are much higher in the Baby Boom Generation than the Silent Generation. More men than women work and they also have higher educational levels but differences are considerably less for Baby Boomers. The country of residence (Germany, Poland, Romania, Russia, Slovenia, Spain, Sweden, Turkey and 
Ukraine) and years covered by the survey (1994 - 1998, 2005 - 2009 y $2010-$ 2014) are included as explanatory variables.

Table 1: Descriptive statistics for dependent and explanatory variables (Data in percentages)

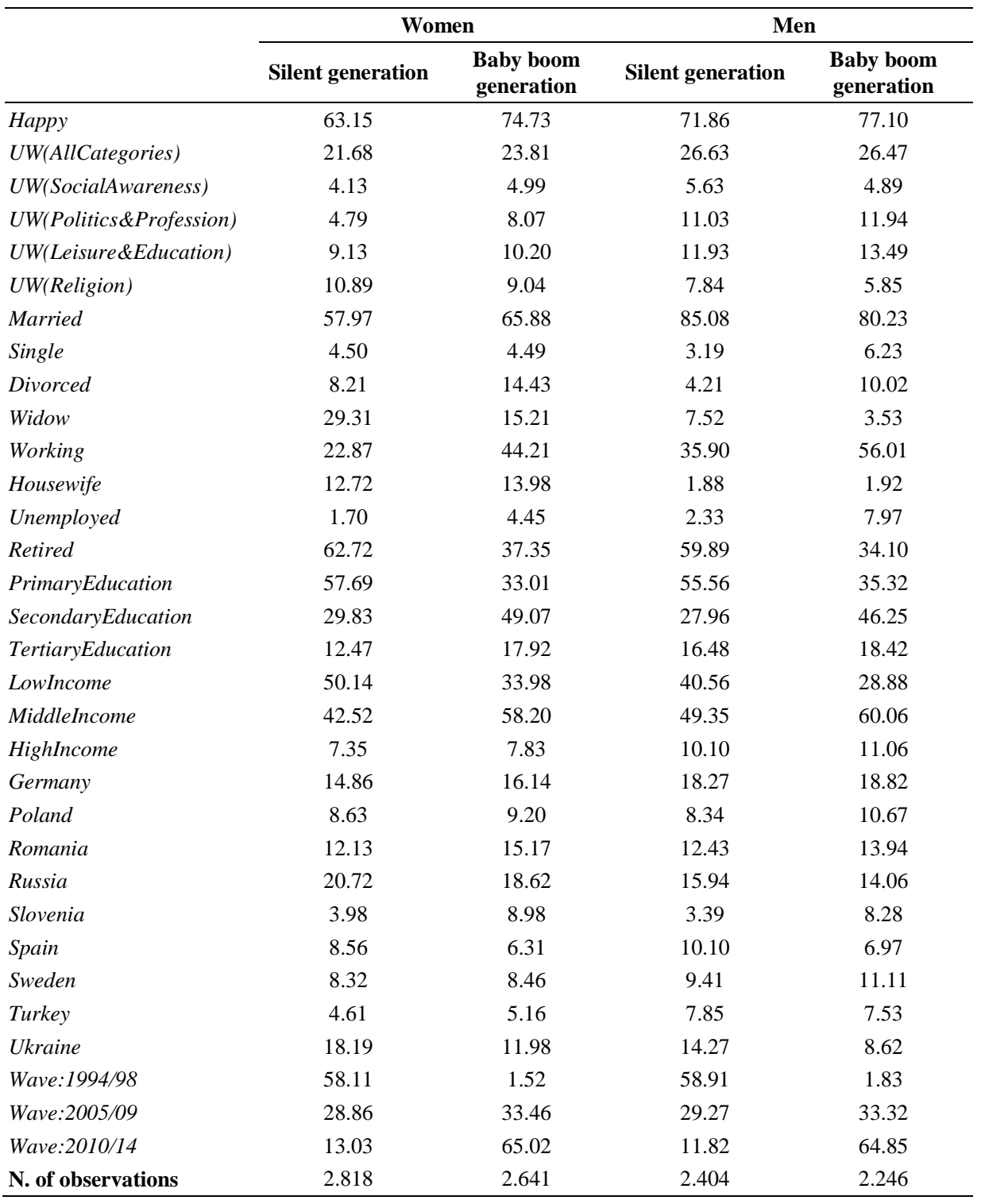

Data: World Value Survey (table designed by the authors)

Total number of observations: 10109 
Figure 2: Percentages of European senior citizens who feel happy and who volunteer: by gender and country of residence $(2010-2014)$

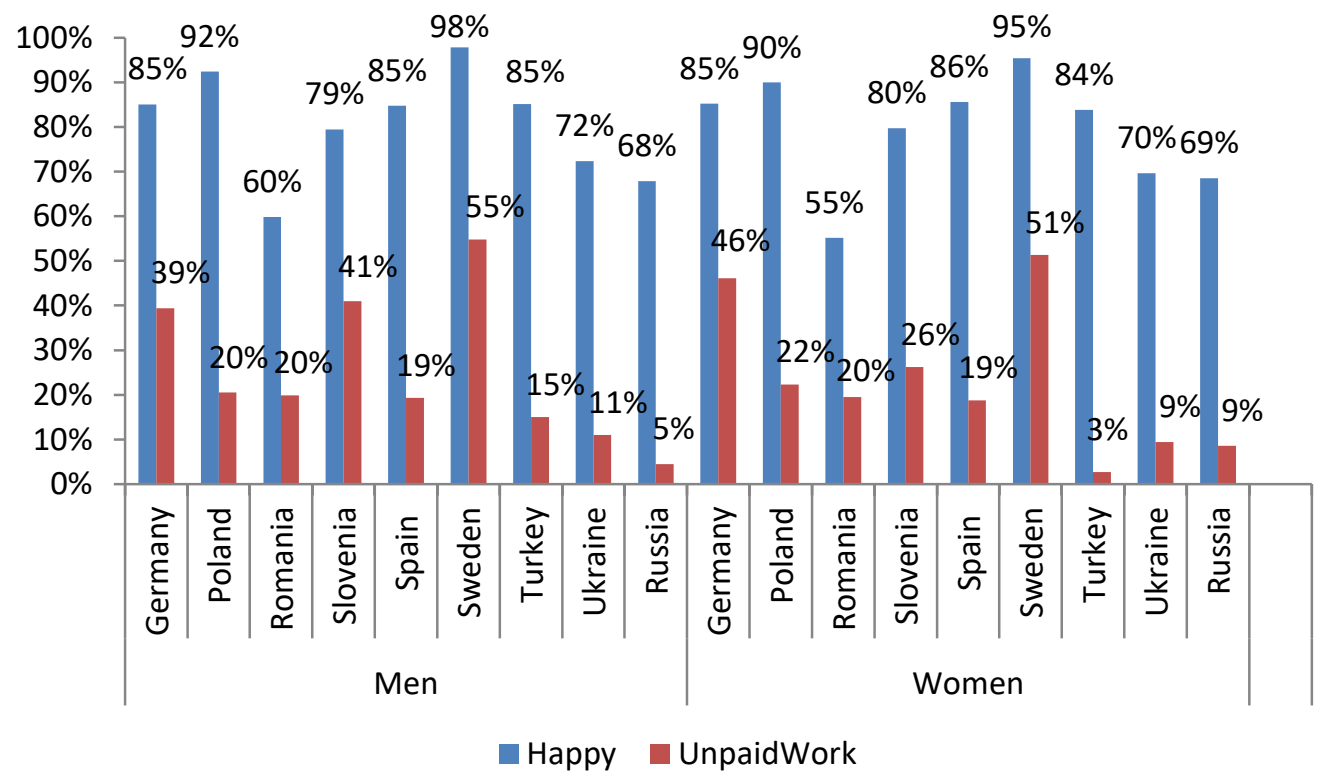

Data: World Value Survey (figure designed by the authors).

\section{Methods}

The main objective of this study is the analysis of the determinants of the wellbeing of European senior citizens; the hypothesis was tested by validating models and econometric estimation techniques which depend on the nature of the data used (cross sectional) and the goals that are set (estimated probabilities).

The first stage employed Multinomial Logit models (reporting results in terms of elasticity) to understand the socioeconomic determinants of being a volunteer and happy $(H U W)$. Dependent variables take four possible values for: NoHappy\&NoVolunteer $(H U W=1)$, NoHappy\&Volunteer $(H U W=2)$, Happy\&NoVolunteer $(H U W=3)$; Happy\&Volunteer $(H U W=4)$. Given the categorical nature of dependent variable we use Multinomial Logit Regressions:

$$
H U W_{i}=\lambda_{0}+\lambda_{1} X_{i}+\lambda_{2} \text { Country }_{i}+\lambda_{3} \text { SurveyYear }+v_{1 i}
$$

The main advantage of equation (1) is that it offers a reliable picture of the influence of socioeconomic variables $\left(X_{i}\right)$, country of residence (Country ${ }_{i}$ ), 
year of survey ( SurveyYear) and a set of unobserved variables summarised in a zero-mean error term $\left(v_{1 i}\right)$ on feeling happy and volunteering decisions for the individual ith. All explanatory variables are exogenous, so there is no bias derived from endogeneity. Estimations were repeated 4 times for gender and generational subsamples (women from the Silent Generation; women from the Baby Boomer Generation; men from the Silent Generation; and men from the Baby Boomer Generation). Differences on estimated parameters reveal gender and generational gaps. If estimated parameters are close for each estimation, results will not provide empirical evidence of gender and/or generational gaps. If the estimated parameters differ among sub-samples, results will bring to light how the effects of explanatory variables on dependent variables vary by gender and/or generational cohort.

The second stage used Simple Logit models (reporting results in terms of elasticity) to understand the impact of both socioeconomic characteristics and volunteering decisions on happiness among European senior citizens:

$$
H_{i}=\beta_{0}+\beta_{1} X_{i}+\beta_{2} U W_{i}+\beta_{3} \text { Country }_{i}+\beta_{2} \text { SurveyYear }+\varepsilon_{1 i}
$$

Feeling happy $\left(H_{i}\right)$ depends on socioeconomic factors $\left(X_{i}\right)$, volunteering decisions $\left(U W_{i}\right)$, country of residence ( Country $y_{i}$ ), year of survey ( SurveyYear) and a set of unobserved variables summarised in a zero-mean error term ( $\left.\varepsilon_{1 i}\right)$. Two models are considered: Model $1 U W_{i}$ includes: $U W$ (AllCategories). Model $2 U W_{i}$ includes $U W$ (SocialAwareness), $U W$ (Politics\&Profession), UW(Leisure\&Education) and UW(Religion). As in the first stage, estimations for Model 1 and Model 2 were repeated four times for gender and generational subsamples. In these models, the key research parameter is $\beta_{2}$ because it gives information on the causal effect of volunteering decisions on feeling happy, controlling for differences in the observed and unobserved determinants of $\left(H_{i}\right)$.The Schmith-Bundell exogeneity test was used to check if volunteering decisions were independent variables. If an explanatory variable is simultaneously explained by the model that defines the dependent variable, then there might be a problem of endogeneity which could generate biased results. Given that the structure of our data is cross-sectional, if there were problems of endogeneity, the estimated results could show correlation effects rather than causality.

For Model 1, the test confirmed that UW(AllCategories) is an endogenous explanatory variable for women from the Silent Generation (the coefficient of 
the residual of volunteering in the estimation of being happy is equal to 8.07 with a z-statistic of 2.42), for women from the Baby Boom Generation (the coefficient of the residual of volunteering in the estimation of being happy is equal to 13.23 with a z-statistic of -3.31), and for men from the Baby Boom Generation (the coefficient of the residual of volunteering in the estimation of being happy is equal to -10.69 with a z-statistic of -2.37 ).

For Model 2, the test confirmed that $U W$ (SocialAwareness) is an endogenous explanatory variable for women from the Baby Boom Generation (the coefficient of the residual of volunteering in the estimation of being happy is equal to -14.38 with a $\mathrm{z}$-statistic of -2.29) and for men from the Silent Generation (the coefficient of the residual of volunteering in the estimation of being happy is equal to -15.77 with a $\mathrm{z}$-statistic of -3.46). As the magnitude of the estimated parameters of volunteering activities were not especially high and the rest of the estimated parameters were robust through the models, it was decided to keep the empirical strategy as simple as possible: it did not include strategies aimed at correcting endogeneity.

\section{Results}

Table 2 presents the socioeconomic determinants of feeling happy and being a volunteer in the case of women. Being single, divorced or widowed reinforces the probability of feeling unhappy and not volunteering and it reduces the probability of feeling happy and not volunteering. The impact of civil status is stronger for feeling happy than for being a volunteer. The impact factor is also stronger for women from the Silent Generation than for women from the Baby Boom Generation. Being a housewife improves the probability of feeling happy for women from the Silent Generation, but has a negative effect on women from Baby Boom Generation. Civil status and employment play a more important role on happiness than on volunteering decisions. Educational level and income reinforce the probability of feeling happy and volunteering and they also reduce the probability of feeling unhappy and not volunteering. Education has a greater impact on women from the Silent Generation than for women from the Baby Boom Generation.

Table 3 shows the corresponding results for men. They are similar to those obtained for women. Being married, working, highly educated and well-off reinforce both happiness and volunteering decisions. Education has a greater impact for men from the Silent Generation than for men from the Baby Boom Generation. 
Table 2: Estimations for Unpaid Work and Happiness among women (Mlogit: Elasticities)

\begin{tabular}{|c|c|c|c|c|c|c|c|c|}
\hline & \multicolumn{4}{|c|}{ Silent generation } & \multicolumn{4}{|c|}{ Baby boom generation } \\
\hline & $\begin{array}{c}\text { No } \\
\text { Happy } \\
\& \\
\text { No UW }\end{array}$ & $\begin{array}{c}\text { No } \\
\text { Happy } \\
\& \\
\text { UW }\end{array}$ & $\begin{array}{c}\text { Happy } \\
\& \\
\text { No UW }\end{array}$ & $\begin{array}{c}\text { Happy } \\
\mathbf{\&} \\
\text { UW }\end{array}$ & $\begin{array}{c}\text { No } \\
\text { Happy } \\
\& \\
\text { No UW }\end{array}$ & $\begin{array}{c}\text { No } \\
\text { Happy } \\
\text { \& } \\
\text { UW }\end{array}$ & $\begin{array}{c}\text { Happy } \\
\& \\
\text { No UW }\end{array}$ & $\begin{array}{c}\text { Happy } \\
\text { \& } \\
\text { UW }\end{array}$ \\
\hline LnAge & $-0.204 *$ & -0.014 & 0.185 & 0.033 & 0.175 & 0.018 & $-0.338 * *$ & 0.145 \\
\hline Married $^{a}$ & -- & -- & -- & -- & -- & -- & -- & -- \\
\hline Single & $0.161 * * *$ & 0.027 & $-0.218 * * *$ & 0.029 & $0.128 * * *$ & 0.023 & $-0.146^{* * * *}$ & -0.006 \\
\hline Divorced & $0.115^{* * *}$ & -0.022 & $-0.126 * * *$ & 0.033 & $0.111 * * *$ & 0.007 & $-0.065^{* *}$ & $-0.053 * *$ \\
\hline Widow & $0.129 * * *$ & $0.027 * * *$ & $-0.148 * * *$ & -0.009 & $0.132 * * *$ & $0.037 * * *$ & $-0.151 * * *$ & -0.017 \\
\hline Working $^{a}$ & -- & -- & -- & -- & -- & -- & -- & -- \\
\hline Housewife & 0.007 & -0.016 & -0.047 & $0.057 * *$ & $0.082 * *$ & $-0.037 * *$ & 0.021 & $-0.067 * *$ \\
\hline Unemployed & $0.145^{* *}$ & -0.004 & -0.081 & -0.060 & 0.082 & 0.006 & 0.025 & $-0.112 * * *$ \\
\hline Retired & $0.051 * *$ & -0.016 & $-0.056^{* *}$ & 0.021 & 0.016 & $-0.022 * *$ & 0.037 & -0.032 \\
\hline PrimaryEducation $^{a}$ & -- & -- & -- & -- & -- & -- & -- & -- \\
\hline $\begin{array}{l}\text { Secondary } \\
\text { Education }\end{array}$ & $-0.057 * * *$ & -0.005 & 0.011 & $0.050 * * *$ & -0.020 & -0.005 & -0.020 & $0.045^{* *}$ \\
\hline TertiartyEducation & $-0.111 * * *$ & 0.015 & -0.011 & $0.107 * * *$ & $-0.060 * *$ & -0.002 & -0.032 & $0.094 * * *$ \\
\hline LowIncome $e^{a}$ & -- & -- & -- & -- & -- & -- & -- & -- \\
\hline MiddleIncome & $-0.036 * *$ & -0.014 & $0.055 * * *$ & -0.004 & $-0.098 * * *$ & -0.012 & $0.053 * * *$ & $0.056^{* * * *}$ \\
\hline HighIncome & $-0.143 * * *$ & -0.018 & $0.094 * * *$ & $0.067 * * *$ & $-0.110 * * *$ & -0.015 & 0.054 & $0.071 * *$ \\
\hline Pseudo-R2 (\%) & \multicolumn{4}{|c|}{17.43} & \multicolumn{4}{|c|}{13.59} \\
\hline $\begin{array}{l}\text { Estimated } \\
\text { probability }(\%)\end{array}$ & 24.70 & 4.90 & 53.92 & 16.70 & 22.18 & 4.92 & 51.86 & 21.69 \\
\hline
\end{tabular}

Results controlled for country and time dummy variables. Female senior citizens from Eastern countries report lower levels (percentages) of happiness and less volunteering activities than female senior citizens from Sweden (country of reference).

$* * *, * *$ and $*$ denote that explanatory variables are statistically significant to $99 \%, 95 \%$ and $90 \%$.

${ }^{a}$ Reference variable. 
Table 3: Estimations for Unpaid Work and Happiness among men (Mlogit: Elasticities)

\begin{tabular}{|c|c|c|c|c|c|c|c|c|}
\hline & \multicolumn{4}{|c|}{ Silent generation } & \multicolumn{4}{|c|}{ Baby boom generation } \\
\hline & $\begin{array}{c}\text { No } \\
\text { Happy } \\
\& \\
\text { No UW }\end{array}$ & $\begin{array}{c}\text { No } \\
\text { Happy } \\
\mathcal{\&} \\
\text { UW }\end{array}$ & $\begin{array}{c}\text { Happy } \\
\& \\
\text { No UW }\end{array}$ & $\begin{array}{c}\text { Happy } \\
\& \\
\text { UW }\end{array}$ & $\begin{array}{c}\text { No } \\
\text { Happy } \\
\& \\
\text { No UW }\end{array}$ & $\begin{array}{c}\text { No } \\
\text { Happy } \\
\mathcal{\&} \\
\text { UW }\end{array}$ & $\begin{array}{c}\text { Happy } \\
\& \\
\text { No UW }\end{array}$ & $\begin{array}{c}\text { Happy } \\
\text { \& } \\
\text { UW }\end{array}$ \\
\hline LnAge & -0.100 & -0.048 & $0.338 * *$ & -0.189 & -0.104 & -0.108 & 0.157 & 0.055 \\
\hline Married $^{a}$ & -- & -- & -- & -- & -- & -- & -- & -- \\
\hline Single & $0.131 * * *$ & $0.033 * *$ & -0.094 & -0.070 & $0.165 * * *$ & $0.035 * *$ & $-0.093 * *$ & $-0.107 * * *$ \\
\hline Divorced & $0.143 * * *$ & $0.044 * * *$ & $-0.150 * * *$ & -0.037 & $0.155^{* * * *}$ & $0.041 * * *$ & $-0.130 * * *$ & $-0.066^{* *} *$ \\
\hline Widow & $0.135 * * *$ & $0.028 * *$ & $-0.134 * * *$ & -0.029 & $0.181 * * *$ & $0.055 * * *$ & $-0.244 * * *$ & 0.008 \\
\hline Working $^{a}$ & -- & -- & -- & -- & -- & -- & -- & -- \\
\hline Housewife & $0.165^{*}$ & -0.008 & $-0.205 * *$ & 0.047 & $0.118 * *$ & 0.016 & 0.013 & $-0.147 * *$ \\
\hline Unemployed & $0.099 * *$ & 0.014 & -0.081 & -0.031 & $0.165 * * *$ & -0.015 & -0.006 & $-0.145 * * *$ \\
\hline Retired & $0.057 * * *$ & -0.013 & $-0.046^{*}$ & 0.002 & $0.057 * * *$ & -0.003 & 0.037 & $-0.091 * * *$ \\
\hline PrimaryEducation $^{a}$ & -- & -- & -- & -- & -- & -- & -- & -- \\
\hline $\begin{array}{l}\text { Secondary } \\
\text { Education }\end{array}$ & $-0.071 * * *$ & -0.009 & 0.016 & $0.064 * * *$ & $-0.045 * *$ & 0.007 & 0.004 & $0.033 *$ \\
\hline TertiartyEducation & $-0.137 * * *$ & 0.011 & -0.014 & $0.140 * * *$ & $-0.093 * * *$ & $0.024 * *$ & $-0.059 *$ & $0.128 * * *$ \\
\hline LowIncome $^{a}$ & -- & -- & -- & -- & -- & -- & -- & -- \\
\hline MiddleIncome & $-0.034 * *$ & $-0.030 * * *$ & 0.022 & $0.042 * *$ & $-0.068 * * *$ & $-0.015^{*}$ & $0.055^{* *}$ & 0.028 \\
\hline HighIncome & -0.044 & $-0.055 * * *$ & 0.006 & $0.093 * * *$ & $-0.076^{* * *}$ & $-0.034 * *$ & $0.079 * *$ & 0.030 \\
\hline Pseudo-R2 (\%) & \multicolumn{4}{|c|}{17.47} & \multicolumn{4}{|c|}{17.60} \\
\hline $\begin{array}{l}\text { Estimated } \\
\text { probability }(\%)\end{array}$ & 26.96 & 4.15 & 46.96 & 21.90 & 25.98 & 4.44 & 49.01 & 20.56 \\
\hline
\end{tabular}

Results controlled for country and time dummy variables.Male senior citizens from Eastern countries report lower levels (percentages) of happiness and less volunteering activities than male senior citizens from Sweden (country of reference).

$* * *, * *$ and $*$ denote that the explanatory variables are statistically significant to $99 \%, 95 \%$ and $90 \%$.

${ }^{\text {a }}$ Reference variable.

With regards to geographical variables, senior citizens living in eastern European countries report lower levels of happiness and less voluntary activities than those that live in the country of reference: Sweden.

Table 4 gives information on volunteering decisions and rates of happiness among women. Volunteering seems to have a positive impact on happiness for women from the Baby Boom Generation but problems of endogeneity revealed by the Schmith-Bundell test mean that this result should be treated with caution. Nevertheless, there is empirical evidence that women who volunteer in activities with religious organisations are happier than those who do not. Results on civil status, employment, education and income were as robust as those shown in Table 2. The finding (Figure 2) that in general, people living in Sweden demonstrate the highest levels of happiness was confirmed. The 
coefficient for people from eastern European countries was particularly negative.

Table 4: Estimations for happiness among women (Logit: Elasticities)

\begin{tabular}{|c|c|c|c|c|}
\hline & \multicolumn{2}{|c|}{ MODEL 1} & \multicolumn{2}{|c|}{ MODEL 2} \\
\hline & $\begin{array}{c}\text { SILENT } \\
\text { GENERATION }\end{array}$ & $\begin{array}{l}\text { BABY BOOM } \\
\text { GENERATION }\end{array}$ & $\begin{array}{c}\text { SILENT } \\
\text { GENERATION }\end{array}$ & $\begin{array}{l}\text { BABY BOOM } \\
\text { GENERATION }\end{array}$ \\
\hline UW(AllCategories) & 0.029 & $0.064 * * *$ & -- & -- \\
\hline UW(SocialAwareness) & -- & -- & -0.032 & 0.033 \\
\hline UW(Politics\&Profession) & -- & -- & 0.036 & 0.055 \\
\hline UW(Leisure\&Education) & -- & -- & 0.061 & -0.011 \\
\hline$U W($ Religion $)$ & -- & -- & 0.037 & $0.072 * *$ \\
\hline LnAge & $0.220^{*}$ & -0.202 & $0.281^{*}$ & -0.194 \\
\hline Married $^{a}$ & -- & -- & -- & -- \\
\hline Single & $-0.181 * * *$ & $-0.152 * * *$ & $-0.192 * * *$ & $-0.153 * * *$ \\
\hline Divorced & $-0.096^{* * *}$ & $-0.116^{* * *}$ & $-0.088 * * *$ & $-0.121 * * *$ \\
\hline Widow & $-0.157 * * *$ & $-0.170 * * *$ & $-0.162 * * *$ & $-0.172 * * *$ \\
\hline Working $^{a}$ & -- & -- & -- & -- \\
\hline Housewife & 0.009 & -0.040 & 0.018 & -0.041 \\
\hline Unemployed & $-0.145^{* *}$ & $-0.085^{* *}$ & $-0.150 * *$ & $-0.092 * *$ \\
\hline Retired & -0.037 & 0.010 & -0.040 & 0.011 \\
\hline PrimaryEducation $^{a}$ & -- & -- & -- & -- \\
\hline SecondaryEducation & $0.060 * * *$ & 0.023 & $0.061 * * *$ & 0.034 \\
\hline TertiartyEducation & $0.095 * * *$ & $0.059 * *$ & $0.094 * * *$ & $0.060^{* *}$ \\
\hline LowIncome $e^{a}$ & -- & -- & -- & -- \\
\hline MiddleIncome & $0.053 * * *$ & $0.107 * * *$ & $0.054 * * *$ & $0.111^{* * * *}$ \\
\hline HighIncome & $0.160 * * *$ & $0.123 * * *$ & $0.161 * * *$ & $0.123 * * *$ \\
\hline Germany & $-0.283 * * *$ & $-0.267 * * *$ & $-0.284 * * *$ & $-0.273 * * *$ \\
\hline Poland & $-0.196^{* * *}$ & $-0.157 * * *$ & $-0.178 * * *$ & $-0.167 * * *$ \\
\hline Romania & $-0.573 * * *$ & $-0.443 * * *$ & $-0.572 * * *$ & $-0.457 * * *$ \\
\hline Russia & $-0.526^{* * * *}$ & $-0.366^{* * *}$ & $-0.524 * * *$ & $-0.382 * * *$ \\
\hline Slovenia & $-0.427 * * *$ & $-0.265^{* * *}$ & $-0.423 * * *$ & $-0.272 * * *$ \\
\hline Spain & $-0.218 * * *$ & $-0.126^{* * *}$ & $-0.215^{* * *}$ & $-0.136 * *$ \\
\hline Sweden $^{a}$ & -- & -- & -- & -- \\
\hline Turkey & -0.079 & $-0.188^{* * *}$ & -0.074 & $-0.192 * * *$ \\
\hline Ukranie & $-0.549 * * *$ & $-0.328 * * *$ & $-0.547 * * *$ & $-0.344 * * *$ \\
\hline Wave: $1994 / 98^{a}$ & -- & -- & -- & -- \\
\hline Wave:2005/09 & $0.045^{* * *}$ & -0.007 & $0.042 *$ & -0.174 \\
\hline Wave:2010/14 & $0.119 * * *$ & 0.087 & $0.115 * * *$ & 0.078 \\
\hline Pseudo-R2 (\%) & 20.38 & 15.43 & 20.44 & 15.44 \\
\hline Estimated prob. (\%) & 70.73 & 70.05 & 72.09 & 72.11 \\
\hline
\end{tabular}

Results controlled for country and time dummy variables

$* * *, * *$ and $*$ denote that the explanatory variables are statistically significant to $99 \%, 95 \%$ and $90 \%$

${ }^{\mathrm{a}}$ Reference variable 
Table 5 gives the results on volunteering decisions and rates of happiness for men. There is evidence that for the Silent Generation, volunteering has a positive effect on happiness, especially if the voluntary work concerns activities related to leisure, education and religion. Civil status, employment, education and income levels reinforce levels of happiness. Education plays a stronger role for men from the Silent Generation whilst income is slightly more relevant for men from the Baby Boom Generation.

In general, men are more sensitive to the impact of socioeconomic factors on their happiness than women. For example, being unemployed has a more negative effect on happiness for men than for women.

\section{Discussion and policy implications}

Strategies for the promotion of happiness and volunteering require prior knowledge about the population characteristics of older adults and senior citizens. The World Happiness Report of 2015 stressed the importance of using happiness measures to guide policymaking and assess overall wellbeing in each society (Helliwell et al. 2015). The results of this present study show a positive relationship between happiness and volunteering, and this implies that governments should promote volunteering as part of a healthy aging agenda, regardless of the welfare system. The promotion of such policies should begin before retirement (Butrica et al. 2009).

Our results indicate that men perceive themselves as happier than women; they are also more likely to volunteer (Gerdtham - Johannesson 2001; Bjørnskov 2008). Adams-Price et al. (2013) suggest that Baby boomers report a lower degree of subjective wellbeing than their predecessors. However, our findings confirm that happiness decreases with age, and it is therefore logical that people from Baby Boom Generation are happier than people from Silent Generation.

Volunteering might have a positive impact on the happiness of senior citizens but it is important to choose activities that promote wellbeing (Binder Freytag 2013). A final observation is that there are gender and generational differences but they are more related to the intensity of the influence rather than the sense of the influence. As Petrova Kafkova (2016) proposes age, gender, socioeconomic status and quality of life show a complex interaction for the case of Czech Republic. Chronological age affects less to wellbeing decline than cultural and economic capital impact on older adults (modulated too by sex). Regarding quality of life determinants, women benefit from higher income more than men, but higher education exert a more positive influence to men than to women. 
Table 5: Estimations for happiness among men (Logit: Elasticities)

\begin{tabular}{|c|c|c|c|c|}
\hline & \multicolumn{2}{|c|}{ MODEL 1} & \multicolumn{2}{|c|}{ MODEL 2} \\
\hline & $\begin{array}{c}\text { SILENT } \\
\text { GENERATION }\end{array}$ & $\begin{array}{c}\text { BABY BOOM } \\
\text { GENERATION }\end{array}$ & $\begin{array}{c}\text { SILENT } \\
\text { GENERATION }\end{array}$ & $\begin{array}{l}\text { BABY BOOM } \\
\text { GENERATION }\end{array}$ \\
\hline$\overline{U W(\text { AllCategories })}$ & $0.092 * * *$ & 0.025 & -- & -- \\
\hline UW(SocialAwareness) & -- & -- & -0.021 & 0.001 \\
\hline UW(Politics\&Profession) & -- & -- & 0.012 & 0.041 \\
\hline UW(Leisure \&Education) & -- & -- & $0.094 * * *$ & 0.023 \\
\hline$U W($ Religion $)$ & -- & -- & $0.114 * * *$ & 0.004 \\
\hline LnAge & 0.163 & 0.202 & $0.261 * *$ & 0.200 \\
\hline Married $^{a}$ & -- & -- & -- & -- \\
\hline Single & $-0.164 * * *$ & $-0.197 * * *$ & $-0.158 * * *$ & $-0.202 * * *$ \\
\hline Divorced & $-0.202 * * *$ & $-0.196 * * *$ & $-0.177 * * *$ & $-0.200 * * *$ \\
\hline Widow & $-0.166 * * *$ & $-0.236^{* * *}$ & $-0.165 * * *$ & $-0.241 * * *$ \\
\hline Working $^{a}$ & -- & -- & -- & -- \\
\hline Housewife & -0.121 & $-0.127 * *$ & -0.131 & $-0.124 *$ \\
\hline Unemployed & $-0.114 * *$ & $-0.151 * * *$ & $-0.120 * *$ & $-0.155 * * *$ \\
\hline Retired & $-0.040 *$ & $-0.050 * * *$ & $-0.050 * *$ & $-0.051 * *$ \\
\hline PrimaryEducation $^{a}$ & -- & -- & -- & -- \\
\hline SecondaryEducation & $0.075^{* * *}$ & $0.037 *$ & $0.082 * * *$ & $0.041 *$ \\
\hline TertiartyEducation & $0.107 * * *$ & $0.064 * *$ & $0.111 * * *$ & $0.072 * *$ \\
\hline LowIncome $^{a}$ & -- & -- & -- & -- \\
\hline MiddleIncome & $0.063 * * *$ & $0.083 * * *$ & $0.071 * * *$ & $0.082 * * *$ \\
\hline HighIncome & $0.100 * * *$ & $0.111 * * *$ & $0.110 * * *$ & $0.113 * * *$ \\
\hline Germany & $-0.187 * * *$ & $-0.308 * * *$ & $-0.191 * * *$ & $-0.309 * * *$ \\
\hline Poland & $-0.161 * * *$ & $-0.158 * * *$ & -0.127 & $-0.154 * *$ \\
\hline Romania & $-0.479 * * *$ & $-0.507 * * *$ & $-0.480 * * *$ & $-0.508 * * *$ \\
\hline Russia & $-0.455 * * *$ & $-0.449 * * *$ & $-0.461 * * *$ & $-0.446 * * *$ \\
\hline Slovenia & $-0.302 * * *$ & $-0.373 * * *$ & $-0.297 * * *$ & $-0.376 * * *$ \\
\hline Spain & $-0.095 *$ & $-0.201 * * *$ & $-0.096^{*}$ & $-0.208 * * *$ \\
\hline Sweden $^{a}$ & -- & -- & -- & -- \\
\hline Turkey & $-0.137 * *$ & $-0.265^{* * *} *$ & $-0.121 * *$ & $-0.266 * * *$ \\
\hline Ukranie & $-0.474 * * *$ & $-0.339 * * *$ & $-0.476 * * *$ & $-0.340 * * *$ \\
\hline Wave: $1994 / 98^{a}$ & -- & -- & -- & -- \\
\hline Wave:2005/09 & 0.025 & 0.020 & 0.012 & 0.008 \\
\hline Wave:2010/14 & $0.105 * * *$ & 0.078 & $0.086^{* * * *}$ & 0.068 \\
\hline Pseudo-R2 (\%) & 24.24 & 19.64 & 24.70 & 19.72 \\
\hline Estimated probability & 68.78 & 68.07 & 69.76 & 69.50 \\
\hline
\end{tabular}

Results controlled for country and time dummy variables

$* * *, * *$ and * denote that the explanatory variables are statistically significant to $99 \%, 95 \%$ and $90 \%$

${ }^{a}$ Reference variable 
Next to gender and age gaps, our results also bring to light important geographical differences: people from Sweden are the happiest and most likely to volunteer; people in Russia are the least happy and the least likely to volunteer. Social participation of older people is not only the result of a personal decision but it is influenced by other factors and barriers (Raymon et al. 2014). In line with previous studies, this work found significant differences in the rates of volunteering in Europe. Eastern European countries have especially low rates of volunteering; the welfare-state regime would seem to be an explanatory variable of these differences (Piagnol - Huppert 2010; Sammuel - Hadjar 2016).

National differences can be attributed to different causes, identifying them is important in order to intervene and facilitate volunteer commitment (Bradley et al. 2014). People in countries with low volunteering rates might be offering informal assistance and there is no time left for formal volunteering (Eisner et al. 2009). Even in Eastern Europe countries, where volunteering rates are usually low, there are important differences as for example high rates of volunteer in Slovakia (Voicu - Voicu 2009).

In addition to psychosocial and socioeconomic explanations, cultural and historical factors could play a role (Piagnol - Huppert 2010). The cultural factors could be analysed from the perspective of shared beliefs, preferences and attitudes with values scales that have been internationally validated (Davidov et al. 2008). Values related to the volunteer are: benevolence, universalism, seeking pleasure, striving for achievement or for personal success (Piagnol - Huppert 2010). Formal volunteering among Baby boomers is more linked to personal satisfaction than to purely altruistic motives (Pruchno 2012). Volunteering is a useful experience to enhance personal agency which contributes to its attractiveness (McMunn et al. 2009).

The measurement of values related to volunteering is linked to the definition of eudemonic wellbeing, the updating of individual potential, commitment, self-acceptance and positive relationships (Ryan - Deci 2001). It would be interesting to use different measures of wellbeing in the same study as they may influence volunteer behaviour in different ways (Son - Wilson 2012). Complementary actions would require a more sophisticated voluntary measurement of volunteering, not just an affirmative or negative answer, but a "dose response" scale (Dulin et al. 2012) by the domain in which the volunteer activity occurs (Son - Wilson 2012), the motivation for the type of volunteering (Pi et al. 2014), volunteer time, regularity (Thoits - Hewitt 2001) permanence (Davila - Chacón 2004) or even by the self-evaluation of the volunteer experience (Morrow - Howell 2010).

Although cohort studies facilitate a generational comparison, it would be interesting to perform a longitudinal analysis over a longer time interval. In 
previous works based on North American and German observations, results led the authors to conclude that volunteering increases wellbeing and happy people tend to become more involved in volunteering activities (Meier - Stutzer 2008; Pielvin - Siegl 2007; Thoits - Hewitt 2001).

Policy makers should consider socioeconomic characteristics when designing effective policies. Generating national economic growth is equally important as encouraging economic development that improves the citizens' life conditions. Employment, education and income are key factors for understanding wellbeing and volunteering. In this sense, our research results are coherent with other studies by reporting a circular trend. On one hand, better educated, wealthier and more sociable societies share a higher probability to perform voluntary work (Voicu - Voicu 2009). On the other hand, higher voluntary rates could be an indicator of citizen democracy and society development (Butorova - Gyarfasova 2010).

This empirical approach has aimed to understand if geographical differences are consequences of population characteristics (such as gender, age or employment). Future research, will verify whether national differences remain after using multilevel models which allows to understand if geographical differences are based on population characteristics or unobserved contextual data. The low number of countries has discouraged this empirical strategy for this study. In addition, information availability of European countries about this topic is not homogeneous. For example, the Slovakian national organization devoted to research and promote volunteering was created one decade ago (Soltres - Gavurova 2016), whereas in Poland, the claim of nongovernmental organizations started after 1989 with the democratic transition (Regulska 1999). Nevertheless, this study is based on European countries because they face comparable challenges related to aging population and the sustainability of national welfare systems. The advantage to control for countries that are geographically close is the fact that they share important similarities which help to isolate differences. For example, in Ukraine the minimum retirement age is increasing gradually to 60 years for women and 62 years for men by 2021, whereas in Spain the retirement age will reach the 67 years in 2027. Including countries as dummy variables in the model allowed us to control for different national backgrounds.

Isabel Saz-Gil is a Lecturer at Business University of Zaragoza, Spain. Saz-Gil is member of The Third Sector's Social and Economic Studies Group, which take part and collaborate with different research networks. These research has resulted in published papers on the journals: Hacienda Pública Española, Ciriec-España: Revista de Economía Pública, Social y Cooperativa, Voluntas: International Journal of Voluntary and Nonprofit Organizations, among others 
Ana Isabel Gil-Lacruz is an empirical health economist at Zaragoza University, Spain. Gil-Lacruz has been recently working in the projects sponsored by the National Institute of Health of the United States and by the Spanish Association of Health Economics. These research has resulted in published papers on the journals: Empirical Economics, The European Journal of Health Economics, Social Indicators Research, among others.

Marta Gil-Lacruz is a Doctor of psychology and sociology. She is currently Tenured Professor of Social Psychology. Her many publications include Health and Sources of Social Support (The Centre for Sociological Research, 2000), A Didactic Guide to Social Psychology (Promolibro, 2004), Social Psychology, a Commitment Applied to Health (University Press, 2007) and numerous articles and collaborations in projects relative to theoretical aspects applied to the social psychology of health, lifestyles and social determinants.

\section{REFERENCES}

ADAMS-PRICE, C. - TURNER, J. - WARREN, S., 2013: Comparing the Future Concerns of Early Wave Baby Boomers with the Concerns of Young-Old Adults. Journal of Applied Gerontology, 34(6). http://dx.doi.org/10.1177/0733464813493135

ANHEIER, H. K. - SALAMON, L. M., 1999: Volunteering in Cross-National Perspective: Initial Comparisons. Law and Contemporary Problems, 62, 43-46.

BAKER, L. - CAHALIN, L. - GERST, K. - BURR, J., 2005: Productive Activities and Subjective Well-Being Among Older Adults. Social Indicators Research, 74, 431-458.

BERKMAN, L. - GLASS, T. - BRISSETTE, I. - SEEMAN, T., 2000: From Social Integration to Health: Durkheim in the New Millennium. Social Science and Medicine, 51, 843-857.

BINDER, M. - FREYTAG, A., 2013: Volunteering, Subjective Well-Being and Public Policy, Journal of Economic Psychology, 34, 97-119.

BJØRNSKOV, C., 2008: Social Capital and Happiness in the United States. Applied Research in Quality of Life, 3, 43-62.

BUTOROVA, Z. - GYARFASOVA, O., 2010: Civic Participation: Trends, Issues and Contexts. Sociologia, 42 (5), 447-491.

BRADLEY, N. - OBST, P. - WHITE, K. M. - LEWIS, I. M. - WARBURTON, J. SPENCER, N. M., 2014: Exploring the Validity and Predictive Power of an Extended Volunteer Functions Inventory Within the Context of Episodic Skilled Volunteering by Retirees. Journal of Community Psychology, 42(1), 1-18.

BUTRICA, B. - JOHNSON, R. W. - ZEDLEWSKI, S. R., 2009: Volunteer Dynamics of Older Americans. Journal of Gerontology: Social Sciences, 64(5), 644-655.

CHEUNG, C. K. - CHENG, J. Y. S., 2016: Resources and Norms as Conditions for Well-Being in Hong Kong. Social Indicators Research, 126(2), 757-775. 
CHONG, A. M. - ROSELLE, T. L. - LIU, S., 2013: Volunteerism and Positive Aging in Hong Kong: A Cultural Perspective. The International Journal of Aging and Human Development, 77(3), 211-231.

Corporation for National and Community Service, 2007: The Health Benefits of Volunteering. Washington, DC: Corporation for National and Community Service, Office of Research and Policy Development.

DAVIDOV, E. - SCHMIDT, P. - SCHWARTZ, S. H., 2008: Bringing Values Back in: The Adequacy of the European Social Survey to Measure Values in 20 Countries. Public Opinion Quarterly, 72(3), 420-445.

DAVILA, M. C. - CHACÓN, F., 2004: Factores psicosociales y tipo de voluntariado. Psicothema, 16(4), 639-645.

DIENER, E., 2006: Guidelines for National Indicators of Subjective Well-Being an IllBeing. Applied Research in Quality of Life, 1, 151-157.

DIENER, E. - SUH, E. - LUCAS, R. - SMITH, H., 1999: Subjective Well-Being: Three Decades of Progress. Psychological Bulletin, 125(2), 276-303.

DOLAN, P. - PEASGOOD, T. - WHITE, M., 2008: Do we Really Know what Makes us Happy? A Review of the Economic Literature on the Factors Associated with Subjective Well-Being. Journal of Economic Psychology, 29, 94-122.

DULIN, P. L. - GAVALA, J. - STEPHENS, C. - KOSTICK, M. - MCDONALD, J., 2012: Volunteering Predicts Happiness Among Older Maori and Non-Maori in the New Zealand Health, Work, and Retirement Longitudinal Study. Aging and Mental Health, 16(5), 617-624.

EASTERLIN, R. A., 2008: Lost in Transition: Life Satisfaction on the Road to Capitalism. Journal of Economic Behavior \& Organization, 71(2), 130-145.

ECHEVERRI, A. - RODRÍGUEZ, M. C. - CORREA, J. C., 2014: Fortalecimiento del capital social a través del voluntariado, caso comuna de una ciudad colombiana. Hallazgos, 22, 199-224.

EISNER, D. - GRIMM, R. - MAYNARD, S. - WASHBURN, S., 2009: The New Volunteer Workforce. Standford Social Innovation Review, Winter, 32-37.

ETZIONI, A., 2011: The New Normal. Sociological Forum, 26(4), 779-789.

FITZPATRICK, T. R. - GITELSON, R. J. - ANDERECK, K. L. - MESBUR, E. S., 2005: Social Support Factors and Health Among a Senior Center Population in Southern Ontario, Canada. Social work in health care, 40(3), 15-37.

FLECHA, A. C., 2015: Well-Being of Senior Residents in Nursing Homes. Pedagogia social, Revista interuniversitaria, 25, 319-341.

FREY, B. S. - STUTZER, A., 2002: Happiness and Economics. Princeton: Princeton University Press.

GERDTHAM, U. G. - JOHANNESSON, M., 2001: The Relationship between Happiness, Health, and Socio-Economic Factors: Results based on Swedish Microdata. Journal of Socio-Economics, 30 (6), 553-557.

GRAHAM, C., 2006: Happiness and Health: Lessons and Questions for Public Policy. Health Affairs, 27(1), 72-87.

GREENFIELD, E. A. - MARKS, N. F., 2004: Formal Volunteering as a Protective Factor for Older Adults' Psychological Well-Being. Journal of Gerontology: Social Sciences 59B(5), S258-S264. 
HANDY, F. - MOOK, L., 2011: Volunteering and Volunteers: Benefit-Cost Analysis. Research on Social Work Practice, 21 (4), 412-420.

HELLIWELL, J. F., 2001: Social Capital, the Economy and Well-Being. In: Banting, K., Sharpe, A., St-Hilarie, F., (Eds.), The Review of Economic Performance and Social Progress. The Longest Decade: Canada in the 1990s. The Institute for Research on Public Policy, Montreal, pp. 43-60.

HELLIWELL, J. - LAYARD, R. - SACHS, J., 2015: World Happiness Report. Retrieved from http://worldhappiness.report/wp-content/uploads/sites/2/2015/04/ WHR15.pdf

HERVÁS, G., 2009: El bienestar de las personas. In: Vázquez, C., Hervás, G., (Eds.), La ciencia del bienestar: Fundamentos de una psicología positiva. Alianza, Madrid, pp. 75-100.

HO, H. C., 2015: Elderly Volunteering and Psychological Well-Being. International Social Work, 25, Retrieved from http://isw.sagepub.com/.

HUPPERT, F. A. - MARKS, N. - CLARK, A. - SIEGRIST, J. - STUTZER, A. VITTERSØ, J. - WAHRENDORF, M., 2009: Measuring Well-Being Across Europe: Description of the EES Well-Being Module and Preliminary Findings. Social Indicator Research, 91 (3), 301-315.

KOMP, K. - JOHANSSON, S., 2016: Population Ageing in a Lifecourse Perspective: Developing a Conceptual Framework. Ageing and Society, 36(9), 1937 - 1960. doi:10.1017/S0144686X15000756

KONRATH, S. - FUHREL-FORBIS, A. - LOU, A. - BROWN, S., 2012: Motives for Volunteering are Associated with Mortality Risk in Older Adults. Health Psychology, 31 (1), 87-96.

KUTI, E., 2004: Civic Service in Eastern Europe and Central Asia: From Mandatory Public Work Toward Civic Service. Nonprofit and Voluntary Sector Quarterly, 33 (4), 79S-97S.

KYE, S.Y. - PARK, K., 2014: Health-Related Determinants of Happiness in Korean Adults. International Journal of Public Health, 59 (5), 731-738.

LANCASTER, L. C. - STILLMAN, D., 2004: When Generations Collide: How to Solve the Generational Puzzle at Work. The Management Forum Series.

LAYARD, R., 2005: Happiness: Lessons from a New Science. London: Penguin.

MATTEN, D. - MOON, J. - MUTHURI, J., 2006: Employee Volunteering and the Creation of Social Capial ICCSR. Resarch Paper Series, 34, 1-34.

MCMAHAN, E. A. - RENKEN, M. D., 2011: Eudaimonic Conceptions of WellBeing, Meaning in Life, and Self-Reported Well-Being: Initial Test of a Mediational Model. Personality and Individual Differences, 51 (5), 589-594.

MCMUNN, A. - NAZROO, J. - WAHRENDORF, M. - BREEZE, E. ZANINOTTO, P., 2009: Participation in Socially-Productive Activities, Reciprocity and Well-Being in Later Life: Baseline Results in England. Ageing and Society, 29 (5), 765-782.

MEIER, S. - STUTZER, A., 2008: Is Volunteering Rewarding in it Self? Economica, $75,39-59$. 
MOLLIDOR, C. - HACKOCK, N. - PEPPER, M., 2015: Volunteering, Religiosity and Well-Being: Interrelationships Among Australian Church Goers. Mental Health Religion and Culture, 18 (1), 20-32.

MORROW-HOWELL, N., 2010: Volunteering in Later Life: Research Frontiers. Journals of Gerontoloy: Psychological and Social Sciences, 65B (4), 461-469.

MORROW-HOWELL, N. - HONG, S. L. - TANG, F., 2009: Who Benefits from Volunteering? Variations in Perceived Benefits. The Gerontologist, 49 (1), 91-102.

MUSICK, M. A. - WILSON, J. - BYNUM, W. B. Jr., 2000: Race and Formal Volunteering: The Differential Effects of Class and Religion. Social Forces, 78 (4), 1539-1570.

NORRISH, J. M. - VELLA-BRODRICK, D. A., 2008: Is the Study of Happiness a Worthy Scientific Pursuit? Social Indicators Research, 87, 393-407.

OLAZABAL, I., 2009: Que sont les Baby-boomers devenus? Aspects sociaux d'une generation vieillissante. Québec: Éditions Nota Bene.

OSHIO, T. - KOBAYASHI, M., 2010: Income Inequality, Perceived Happiness and SelfRated Health: Evidence from Nationwide Surveys in Japan. Social Science \& Medicine, 70, 1358-1366.

PARBOTEEAH, K. P. - CULLEN, J. B. - LIM, L., 2004: Formal Volunteering: A CrossNational Test. Journal of World Business, 39, 431-441.

PETROVA KAFKOVA, M., 2016: The Real Old Age and the Transition between the Third and Foruth Age. Sociologia, 48 (6), 622-640.

PI, L. L. - LIN, Y. H. - CHEN, C. Y. - CHIU, J. C. - CHEN, Y. M., 2014: Serious Leisure, Motivation to Volunteer and Subjective Well-Being of Volunteers in Recreational Events. Social Indicators Research, 119 (3), 1485-1494.

PIAGNOL, A. C. - HUPPERT, F. A., 2010: Happy to Help? Exploring the Factors Associated with Variations in Rates of Volunteering Across Europe. Social Indicator Research, 97, 157-176.

PIEREWAN, A. C. - TAMPUBOLON, G., 2015: Happiness and Health in Europe: A Multivariate Multilevel Model. Applied Research Quality of Life, 10, 237-252.

PILIAVIN, J. - SIEGL, E., 2007: Health Benefits of Volunteering in the Wisconsin Longitudinal Study. Journal of Health and Social Behaviour, 48, 450-464.

PINQUART, M. - SÖRENSEN, S., 2001: Influences on Loneliness in Older Adults: A Meta Analysis. Basic and Applied Social Psychology, 23 (4), 245-266.

PROUTEAU, L. - WOLFF, F. C., 2008: On the Relational Motive for Volunteer Work. Journal of Economic Psychology, 29 (3), 314-335.

PRUCHNO, R., 2012: Not your Mother's Old Age: Baby Boomers at Age 65. The Gerontologist, 52 (2), 149-152.

RAYMOND, É. - GRENIER, A. - HANLEY, J., 2014: Community Participation of Older Adults with Disabilities. Journal of Community \& Applied Social Psychology, 24 (1), $50-62$.

RAYMOND, E. - SEVIGNY, A. - TOURIGNY, A. - VEZINA, A. - VERREAULT, R. GUILBERT, A., 2013: On the Track of Evaluated Programmes Targeting the Social Participation of Seniors: A Typology Proposal. Ageing and Society, 33, 267-296.

RYAN, R. M. - DECI, E. L., 2001: On Happiness and Human Potentials: A Review of Research on Hedonic and Eudaimonic Well-Being. Annual Review of Psychology, 52, 141-166.

RYFF, C. - SINGER, B., 2008: Know Thyself and Become what you are: A Eudaimonic Approach to Psychological Well-Being. Journal of Happiness Studies, 9, 13-39.

Sociológia 51, 2019, No. 3 
SAMUEL, R. - HADJAR, A., 2016: How Welfare-State Regimes Shape Subjective WellBeing Across Europe. Social Indicators Research, 129, 565-587.

SARDINHA, B., 2010: The Economics of the Volunteering Decision. Unpublished Doctoral Thesis. Polytechnic Institute of Setúbal, Portugal.

SEKERAK, M., 2017: The Concepts of Civic Participation and Participatory Democracy through the Lenses of Theory. Sociologia, 49 (2), 179-202.

SELIGMAN, M. E. P., 2002: Authentic Happiness: Using the New Positive Psychology to Realise Your Potential For Lasting Fulfilment. Free Press, New York.

SITHEY, G. - THOW, A. M. - LI, M., 2015: Felicidad nacional bruta y salud: lecciones desde Bhután. Boletín de la Organización Mundial de la Salud, 93, 514.

SOLTRES, V. - GAVUROVA, B., 2016:. Analysis of Selected Socio-Economic Aspects of Volunteering in Slovakia. Economics and Sociology, 8 (2), 183-196.

SON, J. - WILSON, J., 2012: Volunteer Work and Hedonic, Eudemonic and Social WellBeing. Sociological Forum, 27 (3), 658-681.

STUTZER, A. - FREY, B. S., 2006: Does Marriage Make People Happy, or do Happy People get Married? The Journal of Socio-Economics, 35, 326-347.

SUBAS, F. - HAYRAN, O., 2005: Evaluation of Life Satisfaction Index of the Elderly People Living in Nursing Home. Archives of Gerontology and Geriatrics, 41, 23-29.

THEURER, K. - WISTER, A., 2010: Altruistic Behaviour and Social Capital as Predictors of Well-Being Among Older Canadians. Ageing and Society, 30, 157-181.

THOITS, P. A. - HEWITT, L. N., 2001: Volunteer Work and Well-Being. Journal of Health and Social Behaviour, 42 (2), 115-131.

TSE, M. M. Y. - LEE, P. H. - NG, S. M. - TSIEN-WONG, B. K. - YEUNG, S. S. Y., 2014: Peer Volunteers in an Integrative Pain Management Program for Frail Older Adults with Chronic Pain: Study Protocol for a Randomized Controlled trial. Trials, 15, 205.

TWENGE, J. M. - SHERMAN, R. A. - LYUBOMIRSKY, S., 2016. More Happiness for Young People and Less for Mature Adults: Time Period Differences in Subjective WellBeing in the United States, 1972 - 2014. Social Psychological and Personality Science, 7 (2), 131-141.

VAN WILLIGEN, M., 2000: Differential Benefits of Volunteering Across the Life Course. Journal of Gerontology: Social Sciences, 55B(5), S308-S318.

VOICU, B. - VOICU, M., 2009: Volunteers and Volunteering in Central and Eastern Europe. Sociologia, 41 (6), 539-563.

WALLACE, C. - PICHLER, F., 2009: More Participation, Happier Society? A Comparative Study of Civil Society and the Quality of Life. Social Indicators Research, 93 (2), 255-274.

WATERMAN, A. S., 1993: Two Conceptions of Happiness: Contrasts of Personal Expressiveness (eudaimonia) and Hedonic Enjoyment. Journal of Personality and Social Psychology, 64, 678-691.

WILSON, J., 2000: Volunteering. Annual Review of Sociology, 25, 215-240. 